ENCYCLOPEDDIE Encyclopédie berbère

BERBERE

$31 \mid 2010$

31 | Matmora - Meẓrag

\title{
Mesures (Kabylie)
}

\section{S. Chaker}

\section{OpenEdition}

Journals

Édition électronique

URL : http://journals.openedition.org/encyclopedieberbere/574

DOI : $10.4000 /$ encyclopedieberbere. 574

ISSN : 2262-7197

\section{Éditeur}

Peeters Publishers

\section{Édition imprimée}

Date de publication : 30 décembre 2010

Pagination : 4905-4906

ISBN : 978-90-429-2368-3

ISSN : $1015-7344$

\section{Référence électronique}

S. Chaker, « Mesures (Kabylie) », Encyclopédie berbère [En ligne], 31 | 2010, document M96b, mis en ligne le 08 octobre 2020, consulté le 13 octobre 2020. URL : http://journals.openedition.org/ encyclopedieberbere/574; DOI : https://doi.org/10.4000/encyclopedieberbere.574

Ce document a été généré automatiquement le 13 octobre 2020

(c) Tous droits réservés 


\section{Mesures (Kabylie)}

\section{S. Chaker}

1 En Kabylie, les mutations induites par l'ampleur et la profondeur du choc colonial ont très tôt bouleversé le système traditionnel d'échanges économiques. Déjà au milieu du $\mathrm{XIX}^{\mathrm{e}}$ siècle, si l'on en croit Hanoteau et Letourneux, le système des poids et mesures en vigueur en Kabylie était à la fois lacunaire et très instable. Il s'ensuit que, pour les distances, les surfaces, les volumes ou les poids, dans la Kabylie contemporaine le système traditionnel de mesures a été largement abandonné au profit du système métrique introduit par les Français et généralisé par l'intégration dans le tissu économique algérien et mondial.

2 Même si une certaine prudence s'impose car on ne dispose pas de travaux méthodiques sur le sujet, il semble bien que du système ancien, il ne reste guère que des bribes, d'usage général comme ixil, "coudée » désormais définie comme "demi-mètre » $(50 \mathrm{~cm})$ ou ardel, « livre » $(=500 \mathrm{~g})$, ou très spécialisé et propres à certains commerces, professions et travaux féminins, tous en nette régression. Sous réserve donc d'enquêtes à réaliser dans certains milieux professionnels, la plupart des termes anciens (amehraz, amud, acbar, ass n tyirza, aqerwi, lqella, tteebga, uraw, asurif...), s'ils sont encore connus à travers la poésie et les contes, n'évoquent plus rien de précis pour la grande majorité des Kabyles.

Quelques mesures de longueur demeurent cependant d'usage tout à fait courant mais ne s'intègrent plus dans un système cohérent et fonctionnel de références métrologiques, pour n'être plus que des ordres de grandeur vagues : tardast, " empan », imi-mušš, " gueule (ouverte) de chat »)...

4 On trouvera une brève synthèse sur le sujet dans HANOTEAU \& LETOURNEUX, La Kabylie et les coutumes kabyles, vol. I, Editions Bouchène, 2003 (seconde édition augmentée) : « Poids et mesures », p. 451-453. 
INDEX

Mots-clés : Economie, Kabylie, Ethnologie, Ethnographie, Technologie 